\title{
Olive oil bioactive compounds increase body weight, and improve gut health and integrity in gilthead sea bream (Sparus aurata)
}

\author{
Enric Gisbert $^{1 *}$, Karl B. Andree ${ }^{1}$, José C. Quintela ${ }^{2}$, Josep A. Calduch-Giner ${ }^{3}$, Ignacio R. Ipharraguerre ${ }^{4}$ \\ and Jaume Pérez-Sánchez ${ }^{3}$ \\ ${ }^{1}$ Institut de Recerca i Tecnologia Agroalimentàries, Centre de Sant Carles de la Ràpita, Institut de Recerca i Tecnologia \\ Agroalimentàries, Centre de Sant Carles de la Ràpita, IRTA-SCRIRTA-SCR in, Unitat de Cultius Aqüícoles, Crta. Poble Nou del \\ Delta km 5.5, Sant Carles de la Rápita 43540, Spain \\ ${ }^{2}$ ProNutra Solutions SL, Faraday 7, Madrid 28049, Spain \\ ${ }^{3}$ Department of Marine Species Biology, Culture and Pathology, Nutrigenomics and Fish Growth Endocrinology Group, \\ Institute of Aquaculture Torre de la Sal, 12595, Castellón, CSIC, Spain \\ ${ }^{4}$ Institute of Human Nutrition and Food Science, Kiel University, D-24098 Kiel, Germany \\ (Submitted 15 September 2016 - Final revision received 15 December 2016 - Accepted 16 January 2017- First published online 1 March 2017)
}

\section{Abstract}

An olive oil bioactive extract (OBE) rich in bioactive compounds like polyphenols, triterpenic acids, long-chain fatty alcohols, unsaturated hydrocarbons, tocopherols and sterols was tested (0, 0.08, 0.17, 0.42 and 0.73\% OBE) in diets fed to sea bream (Sparus aurata) (initial weight: 5.4 (SD 1.2) g) during a 90-d trial (four replicates). Fish fed diets containing 0.17 and 0.42\% OBE were 5\% heavier (61.1 (SD 1.6) and 60.3 (sD 1.1) g, respectively) than those of the control group (57.0 (SD 0.7) g), although feed conversion ratio and specific feed intake did not vary. There were no differences in lipid peroxidation (LPO) levels, catalase, glutathione reductase and glutathione $S$-transferase activities in the intestine and liver, although there was a tendency of lower intestinal and hepatic LPO levels in fish fed OBE diets. No differences in villus size were found among treatments, whereas goblet cell density in the control group was on average $14.3 \%$ lower than in fish fed OBE diets. The transcriptomic profiling of intestinal markers, covering different biological functions like (i) cell differentiation and proliferation, (ii) intestinal permeability, (iii) enterocyte mass and epithelial damage, (iv) IL and cytokines, (v) pathogen recognition receptors and (vi) mitochondria function, indicated that among the eighty-eight evaluated genes, twenty-nine were differentially expressed ( $0.17 \%$ OBE diet), suggesting that the additive has the potential of improving the condition and defensive role of the intestine by enhancing the maturation of enterocytes, reducing oxidative stress, improving the integrity of the intestinal epithelium and enhancing the intestinal innate immune function, as gene expression data indicated.

\section{Key words: Functional feeds: Gilthead sea bream: Gut health: Olive oil}

The Mediterranean diet has been widely reported to be a model of healthy eating for its contribution to a favourable health status and a better quality of life ${ }^{(1)}$. Olive oil, along with fruits, vegetables and fish, is an important constituent of this diet, and is considered a major factor in preserving a healthy and relatively disease-free population ${ }^{(2)}$. Olive oil contains a high level of MUFA, as well as multiple minor components with biological properties $^{(3)}$. The saponiable fraction of olive oil is primarily composed of TAG, partial glycerides, esters of fatty acids or free fatty acids and phosphatides, which represent nearly $98 \%$ of the oil chemical composition, whereas its unsaponifiable fraction is dominated by minor compounds such as tocopherols, phytosterols, carotenoids ( $\beta$-carotene and lutein), triterpenic alcohols (uvaol and erythrodiol), pentacyclic triterpenes (oleanolic and maslinic acid) and phenolic compounds (i.e. tyrosol, hydroxytyrosol, oleocanthal, oleuropein $)^{(4,5)}$.
A plethora of studies have reported health benefits of olive oil and its minor components in humans, especially in preventing and/or reducing hypercholesterolaemia, serum lipoprotein levels and atherosclerosis, hypertension, CVD and thrombotic risk, oxidation and oxidative stress, obesity and type 2 diabetes, inflammatory processes and cancer ${ }^{(4,6,7)}$. Although there is information about the use of olive oil as substitute of fish oil in aqua feeds ${ }^{(8)}$, published evidence about the use of olive oil and its derivatives as feed additives is scarce, with most of the available information being focused on maslinic acid with contradictory results regarding the potential effects of this triterpenic compound in promoting fish growth performance ${ }^{(9-11)}$.

Supporting fish growth was one of the main objectives of feed producers and fish farmers during the last decades when the efficiency of nutrient conversion and assimilation was one

Abbreviations: BW, body weight; $\mathrm{BW}_{f}$, final body weight; $\mathrm{C}_{t}$, cycle threshold; LPO, lipid peroxidation; OBE, olive oil bioactive extract; SL $\mathrm{L}_{f}$, inal standard length. 
of their main targets of the industry; however, the development of this sector, as well as the intensification of production and strong competition among producers, has forced the sector to reduce production costs for improved economies of scale and find ways to create a competitive edge. In this context, maintaining fish health and welfare is a concern in aquaculture, particularly in the light of the potential effects of climate change and super intensification of the production. Moreover, new management strategies are needed to support growth and health ${ }^{(12)}$. Thus, the use of functional feeds may be regarded as the future of aquaculture; by embracing nutritional strategies to address specific stresses, environmental situations, life stage requirements and pathologies, the industry can optimise animal performance as well as operational efficiency when health improvements lead to reduced production losses. Thus, in the present study, we decided to test the potential benefits of an olive oil bioactive extract (OBE) (unsaponifiable fraction) rich in polyphenols, triterpenic acids, long-chain fatty alcohols, unsaturated hydrocarbons, tocopherols and sterols in terms of growth, feed utilisation, and gut health and integrity in gilthead sea bream (Sparus aurata).

\section{Methods}

\section{Experimental diets}

A control diet was formulated with high levels of marinederived protein sources to contain $53 \%$ crude protein, $18 \%$ crude fat and $20.9 \mathrm{MJ} / \mathrm{kg}$ gross energy and fulfil the nutritional requirements of juvenile sea bream ${ }^{(13)}$. Based on this basal formulation, four additional diets were produced by adding at the expense of fish oil an olive oil containing 9\% triterpenic acids, 2\% polyphenols, $2 \%$ long-chain fatty alcohols and $1 \%$ sterols (OBE, OLEA OS-15 FBP; ProNutra Solutions S.L.) (Table 1). Diets were manufactured by Sparos Lda. Main ingredients were ground (below $250 \mu \mathrm{m}$ ) in a micropulverizer hammer mill (Hosokawa Micron). Powder ingredients and oils were then mixed according to the target formulation in a paddle mixer (RM90; Mainca). All diets were manufactured by temperature controlled extrusion (pellet sizes: 0.8 and $1.5 \mathrm{~mm}$ ) by means of a low-shear extruder (P55; Italplast). Upon extrusion, all feed batches were dried in a convection oven (OP 750-UF; LTE Scientific) for $4 \mathrm{~h}$ at $45^{\circ} \mathrm{C}$. Samples of each diet were analysed for proximate composition analysis (Table 1).

\section{Animals, experimental conditions and general procedures}

Gilthead sea bream fingerlings were obtained from a fish farm (Piscicultura Marina Mediterránea SL), transported by road to the IRTA-SCR facilities and acclimated for $10 \mathrm{~d}$ to new husbandry and water conditions in a $2 \mathrm{~m}^{3}$ circular fiberglass tank. During this period, fish were fed twice a day with Microbaq 15 (Dibaq SA) at $2 \%$ of the stocked biomass. Before the onset of the trial, all fish were anaesthetised (tricaine methanesulfonate, MS-222, $150 \mathrm{mg} / \mathrm{l}$ ), individually weighted (body weight (BW)) and measured for standard length (SL) to the nearest $0 \cdot 1 \mathrm{~g}$ and $1 \mathrm{~mm}$, respectively; and then distributed into twenty fiberglass cylindrical tanks of 400 litres (seventy-five fish per tank, $\left.\mathrm{BW}_{i}=5 \cdot 4(\mathrm{sD} 1 \cdot 2) \mathrm{g}\right)$.

Water temperature and $\mathrm{pH}$ ( $\mathrm{pH}$ meter 507; Crison Instruments), salinity (MASTER-20T; ATAGO Co. Ltd) and dissolved $\mathrm{O}_{2}$ (OXI330; Crison Instruments) were $22 \cdot 1$ (SD $\left.0 \cdot 2\right)^{\circ} \mathrm{C}, 7 \cdot 8$ (sD $0 \cdot 1$ ), $36 \mathrm{mg} / \mathrm{l}$ and $6 \cdot 8$ (sD $0 \cdot 3$ ) $\mathrm{mg} / \mathrm{l}$, respectively. Water flow rate in experimental tanks was maintained at approximately $9.01 / \mathrm{min}$ via a recirculation system (IRTAmar ${ }^{\circledR}$ ) that maintained adequate water quality (total ammonia and nitrite were $\leq 0 \cdot 10$ and $0.4 \mathrm{mg} / \mathrm{l}$, respectively) through $\mathrm{UV}$, biological and mechanical filtration. Photoperiod followed natural changes according to the season of the year (January-April; latitude $\left.40^{\circ} 37^{\prime} 41^{\prime} \mathrm{N}\right)$. Each diet was tested with four replicates for $90 \mathrm{~d}$. Diets were distributed eight times per $\mathrm{d}$ by automatic feeders (ARVO-TEC T Drum 2000; Arvotec) at the rate of 3.3\% of the stocked biomass, which approached apparent satiation.

Sampling to monitor fish growth took place monthly from the onset of the feeding period. For that purpose, all fish in each tank were netted, anaesthetised and their wet BW and SL determined. At the end of the trial ( $90 \mathrm{~d}$ ), all fish from each tank were measured for their final $\mathrm{BW}\left(\mathrm{BW}_{f}, \mathrm{~g}\right)$ and final standard length $\left(\mathrm{SL}_{f}, \mathrm{~cm}\right)$, as well as for determining final size distribution in $\mathrm{BW}_{f}$. In addition, seventy-two specimens (fasted overnight) per experimental group (eighteen per tank) were killed with an overdose of anaesthetic for assessing the histological organisation of the of the intestinal mucosa, the activity of antioxidative stress enzymes in the intestine and liver (five per tank), proximate carcass composition (five per tank) and gene expression analysis of markers of intestinal integrity and health (eight per tank). Fish growth and feed utilisation from different experimental groups was evaluated by means of the following indices: Fulton's condition factor $(K)=\left(\mathrm{BW}_{f} / \mathrm{SL}_{f}^{3}\right) \times 100$; specific growth rate in $\mathrm{BW}$ $\left(\mathrm{SGR}_{B W}, \%\right)=\left(\left(\ln \mathrm{BW}_{f}-\ln \mathrm{BW}_{i}\right) \times 100\right) /$ time $(\mathrm{d})$; feed conversion ratio $(\mathrm{FCR}, \mathrm{g} / \mathrm{g})=F /\left(\mathrm{B}_{f}-\mathrm{B}_{i}\right)$ and apparent specific feed intake $(\mathrm{SFI}, \%)=\mathrm{SGR} \times \mathrm{FCR}$, where $F$ was the total feed intake during the experimental period considered $(\mathrm{g})$ and, $\mathrm{B}_{i}$ and $\mathrm{B}_{f}$ were the initial and final biomass (g).

All animal experimental procedures were conducted in compliance with the experimental research protocol approved by the Committee of Ethics and Animal Experimentation of the Institut de Recerca i Tecnologia Agroalimentàries and in accordance with the Guidelines of the European Union Council $(86 / 609 / \mathrm{EU})$ for the use of laboratory animals.

\section{Proximate composition, lipid peroxidation and antioxidative stress enzymes in liver and intestine}

For determining the body proximate composition of fish and feed, samples were homogenised (Ultra-Turrax T25 basic, IKA ${ }^{\odot}$; Werke), and small aliquots were dried $\left(120^{\circ} \mathrm{C}\right.$ for $\left.24 \mathrm{~h}\right)$ to estimate water content. The total fat content in samples was quantified gravimetrically after extraction in chloroform-methanol (2:1) and evaporation of the solvent under a stream of $\mathrm{N}_{2}$ followed by vacuum desiccation overnight ${ }^{(14)}$. Protein content was determined according to Lowry et $a l^{(15)}$. Ash contents were determined by keeping the sample at $500-600^{\circ} \mathrm{C}$ for $24 \mathrm{~h}$ in 
Table 1. Ingredient list and proximate chemical composition (in DM) of experimental diets

\begin{tabular}{|c|c|c|c|c|c|}
\hline \multirow[b]{2}{*}{ Ingredients ( $\mathrm{g} / 100 \mathrm{~g}$ feed) } & \multicolumn{5}{|c|}{ Diets } \\
\hline & A & B & C & D & $\mathrm{E}$ \\
\hline Fishmeal 70LT* & 33.00 & 33.00 & 33.00 & 33.00 & 33.00 \\
\hline Fishmeal $65 \dagger$ & 6.00 & 6.00 & $6 \cdot 00$ & $6 \cdot 00$ & 6.00 \\
\hline CPSP 90‡ & 7.50 & 7.50 & 7.50 & 7.50 & 7.50 \\
\hline Squid meal§ & 7.50 & 7.50 & 7.50 & $7 \cdot 50$ & $7 \cdot 50$ \\
\hline Soyabean protein concentratell & 5.00 & 5.00 & 5.00 & 5.00 & $5 \cdot 00$ \\
\hline Wheat gluten $\uparrow$ & 8.00 & 8.00 & $8 \cdot 00$ & $8 \cdot 00$ & 8.00 \\
\hline Maize gluten ${ }^{\star *}$ & $2 \cdot 20$ & $2 \cdot 20$ & $2 \cdot 20$ & $2 \cdot 20$ & $2 \cdot 20$ \\
\hline Micronised soyabean meal†† & $5 \cdot 00$ & $5 \cdot 00$ & $5 \cdot 00$ & $5 \cdot 00$ & 5.00 \\
\hline Wheat mealł‡ & $5 \cdot 00$ & $5 \cdot 00$ & $5 \cdot 00$ & $5 \cdot 00$ & $5 \cdot 00$ \\
\hline Pea starch§§ & 4.00 & 4.00 & 4.00 & 4.00 & 4.00 \\
\hline Concentrated olive oil (OLEA OS-15 FBP) & - & 0.08 & $0 \cdot 17$ & 0.42 & 0.73 \\
\hline Fish oill II & $13 \cdot 16$ & 13.08 & 13.01 & $12 \cdot 74$ & $12 \cdot 43$ \\
\hline Vitamin and mineral premix $\uparrow$ & $1 \cdot 20$ & $1 \cdot 20$ & 1.20 & 1.20 & 1.20 \\
\hline Vitamin $E^{\star \star \star}$ & $0 \cdot 10$ & $0 \cdot 10$ & $0 \cdot 10$ & $0 \cdot 10$ & $0 \cdot 10$ \\
\hline Soya lecithin & 0.30 & 0.30 & 0.30 & 0.30 & 0.30 \\
\hline Binder (guar gum) & 1.00 & 1.00 & 1.00 & 1.00 & 1.00 \\
\hline Antioxidant (dry form)††† & 0.20 & $0 \cdot 20$ & 0.20 & 0.20 & 0.20 \\
\hline \multicolumn{6}{|l|}{ 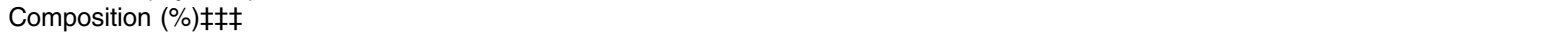 } \\
\hline $\mathrm{CP}$ & 53.1 & 53.1 & 53.0 & 53.1 & $53 \cdot 0$ \\
\hline Fat & $18 \cdot 4$ & $18 \cdot 3$ & $18 \cdot 4$ & $18 \cdot 4$ & $18 \cdot 4$ \\
\hline Ash & $10 \cdot 7$ & $10 \cdot 7$ & $10 \cdot 8$ & $10 \cdot 7$ & $10 \cdot 6$ \\
\hline Fibre & 0.6 & 0.6 & 0.6 & 0.6 & 0.6 \\
\hline Nitrogen free extractive matter & 8.5 & $9 \cdot 6$ & $9 \cdot 6$ & 9.5 & $9 \cdot 7$ \\
\hline Moisture & $7 \cdot 7$ & $7 \cdot 7$ & $7 \cdot 6$ & 7.7 & $7 \cdot 7$ \\
\hline GE $(\mathrm{MJ} / \mathrm{kg}) \S \S \S$ & $21 \cdot 4$ & $21 \cdot 4$ & $21 \cdot 4$ & $21 \cdot 4$ & 21.4 \\
\hline
\end{tabular}

$\mathrm{CP}$, crude protein; $\mathrm{CF}$, crude fat.

* Peruvian fishmeal LT: $71 \%$ CP, $11 \%$ CF, Exalmar.

† Fair average quality fishmeal: $62 \% \mathrm{CP}, 12 \% \mathrm{CF}$, COFACO.

‡ Soluble fish-protein concentrate (CPSP 90): $84 \%$ CP, $12 \%$ CF, Sopropêche.

§ Super prime squid meal: $80 \% \mathrm{CP}, 3.5 \% \mathrm{CF}$, Sopropêche.

${ }$ S Soycomil $^{\odot}$ Soy Protein concentrate: $65 \%$ CP, $1 \%$ CF, ADM.

T VITEN: $85.7 \%$ CP, $1.3 \%$ CF, ROQUETTE.

** $61 \%$ CP, $6 \%$ CF COPAM.

†† Micronised soyabean meal: $51 \cdot 7 \% \mathrm{CP}, 2.1 \% \mathrm{CF}$, Sorgal SA.

‡¥ CP $11.6 \%$, CF $1.4 \%$, Casa Lanchinha.

$\S \S \mathrm{CP} 0.3 \%, \mathrm{CF}<0.1 \%$, Cosucra.

II II Marine oil omega 3: Henry Lamotte Oils GmbH.

Tी PVO40.01 premix for marine fish, PREMIX Lda. Vitamins ( $\mathrm{mg} / \mathrm{kg}$ diet): DL-a tocopherol acetate, $100 \mathrm{mg}$; sodium menadione bisulphate, $25 \mathrm{mg}$; retinyl acetate, $6.88 \mathrm{mg}$; DL-cholecalciferol, $0.050 \mathrm{mg}$; thiamin, $30 \mathrm{mg}$; riboflavin, $30 \mathrm{mg}$; pyridoxine, $20 \mathrm{mg}$; $B_{12}, 0.1 \mathrm{mg} ;$ nicotinic acid, $200 \mathrm{mg}$; folic acid, $15 \mathrm{mg}$; ascorbic acid, $1000 \mathrm{mg}$; inositol, $500 \mathrm{mg}$; biotin, $3 \mathrm{mg}$; calcium panthotenate, $100 \mathrm{mg}$; choline chloride, $1000 \mathrm{mg}$, betaine, $500 \mathrm{mg}$. Minerals (g or mg/kg diet): cobalt sulphate, $2.5 \mathrm{mg}$; copper sulphate, $1.1 \mathrm{mg}$; ferric citrate, $0.2 \mathrm{~g}$; potassium iodide, $5 \mathrm{mg}$; manganese sulphate, $15 \mathrm{mg}$; sodium selenite, $0.2 \mathrm{mg}$; zinc sulphate, $40 \mathrm{mg}$; magnesium hydroxide, $0.6 \mathrm{~g}$; potassium chloride $1.1 \mathrm{~g}$; sodium chloride, $0.5 \mathrm{~g}$; calcium carbonate, $4 \mathrm{~g}$.

*** LUTAVIT E 50, ENSOL.

t†† Paramega PX, Kemin Europe NV.

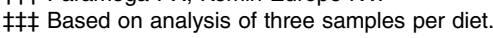

$\S \S \S$ Gross energy content was estimated by using the following: total carbohydrate $\times 17.2 \mathrm{~J} / \mathrm{kg}$, fat $\times 39.5 \mathrm{~J} / \mathrm{kg}$, and protein $\times 23.5 \mathrm{~J} / \mathrm{kg}$.

a muffle furnace ${ }^{(16)}$. All chemical analyses were performed in triplicate per fish and feed samples.

Approximately $100 \mathrm{mg}$ of tissue per sample was homogenised for $5 \mathrm{~min}$ in eight volumes (v/w) of $0 \cdot 15 \mathrm{~m} \mathrm{KCl-KOH,} 1 \mathrm{~mm}$-EDTA $(\mathrm{pH} 7.5)$ buffer and then subjected to sonication (Vibra-Cell ${ }^{\odot}$; Sonics) for $1.5 \mathrm{~min}$ at $0-4^{\circ} \mathrm{C}$. Homogenised samples were centrifuged at $10200 \mathrm{~g}$ for $5 \mathrm{~min}$ at $4^{\circ} \mathrm{C}$, and the supernatant collected for analytical determinations. Quantification of lipid peroxidation (LPO) in the intestine and liver was conducted using the thiobarbituric acid reactive substances method described by Solé $e t a l .{ }^{(17)}$. In brief, LPO was measured using $200 \mu \mathrm{l}$ of the homogenate mixed with $650 \mu \mathrm{l}$ of methanol, 1-methyl-2phenylindole (solution stock of $10.3 \mathrm{~mm}$ ) in acetonitrile-methanol $(1: 3, \mathrm{v} / \mathrm{v})$ and $150 \mu \mathrm{l}$ of $37 \% \mathrm{HCl}$. This mixture was incubated $\left(40 \mathrm{~min}, 45^{\circ} \mathrm{C}\right.$ ), cooled on ice and centrifuged at $21000 \boldsymbol{g}$ for $10 \mathrm{~min}$ to remove protein precipitates. Absorbance was read at $586 \mathrm{~nm}$, and the amount of peroxidised lipids (in nmol malondialdehyde/100 g tissue, w/w) was evaluated by means of a calibration curve made of a standard solution (10 mм 1,1,3, 3-tetramethoxypropane). Homogenised samples, prepared for the determination of LPO, were used to measure activity of antioxidant enzymes. Catalase (CAT, EC 1.11.1.6) activity was measured by the decrease in absorbance at $240 \mathrm{~nm}$ $\left(e=43.6 \mathrm{~mm}^{-1} \times \mathrm{cm}^{-1}\right)$ using $50 \mathrm{~mm}-\mathrm{H}_{2} \mathrm{O}_{2}$ as substrate ${ }^{(18)}$. Glutathione $S$-transferase (GST, EC 2.5.1.18) was assayed by the formation of glutathione chlorodinitrobenzene adduct at $340 \mathrm{~nm}$ $\left(e=9.6 \mathrm{~mm}^{-1} \times \mathrm{cm}^{-1}\right.$ ), using $1 \mathrm{~mm}$ 1-chloro-2,4-dinitrobenzene and $1 \mathrm{~mm}$ glutathione as substrates ${ }^{(19)}$. Glutathione reductase (GR, EC 1.8.1.7) activity was determined by measuring the oxidation of NADPH at $340 \mathrm{~nm}\left(e=6.22 \mathrm{~mm}^{-1} \times \mathrm{cm}^{-1}\right)$, using $20 \mathrm{~mm}$ glutathione disulphide and $2 \mathrm{~mm} \mathrm{NADPH}$ as substrates ${ }^{(20)}$. Enzyme activities were expressed as specific enzyme activities (nmol/minper mg protein), and soluble protein determined by the Bradford method ${ }^{(21)}$. All assays were conducted in triplicate 
at $25^{\circ} \mathrm{C}$, and absorbance read using a spectrophotometer (Tecan ${ }^{\mathrm{TM}}$ Infinite M200; Techan Group Ltd).

\section{Histological organisation of the intestine}

For histological purposes, fragments of liver, mid and posterior intestine from twenty fish per dietary treatment were dissected and fixed in $4 \%$ buffered formaldehyde $(\mathrm{pH}=7 \cdot 4)$, dehydrated in a graded series of ethanol, cleared with xylene, embedded in paraffin and cut in serial sections ( $3-5 \mu \mathrm{m}$ thick). Sections were stained with Masson's trichrome stain for general histological descriptions, whereas slides were stained with Periodic Acid Schiff for goblet cell identification (neutral mucins produced in intestinal goblet cells stain in magenta). All sections were observed under a light microscope (Leica DM LB; Leica Microsystems) and photographed (Olympus DP70 Digital Camera; Olympus Imaging Europa $\mathrm{GmbH})$. Digital images were processed and analysed using an image analysis software package (ANALYSIS; Soft Imaging Systems GmbH). Measurements of total goblet cell number (full and empty) and villi height were based on the analysis of eight to ten randomly chosen fields from the intestinal mucosa. Goblet cell counts in intestinal villi were expressed over a contour length of $100 \mu \mathrm{m}$, whereas villi height and width were calculated according to Escaffre $e t a l .{ }^{(22)}$. Size (S) of hepatic fat deposits (unstained vacuoles within hepatocytes that corresponded to lipids dissolved during the embedding process of the tissue in paraffin) was estimated at $\times 400$ magnification according to the formula: $S\left(\mu \mathrm{m}^{2}\right)=1 / 4 \times \pi \times a \times b$, where $a$ and $b$ were the minimum and maximum diameters of the vacuole ${ }^{(23)}$.

\section{Quantitative PCR and gene expression analyses of intestinal markers}

Total RNA was extracted from the mid-posterior intestine of fish using the TRIzol reagent (Invitrogen ${ }^{\circledR}$ ) as specified by the manufacturer. The quantity of RNA isolated was determined using a Gene-Quant spectrophotometer (Amersham Biosciences), measuring optical density at $260 \mathrm{~nm}$, its purity was established by the absorbance ratio 260:280 nm, and quality of the RNA was evaluated using $1.2 \%$ agarose gel electrophoresis. A reverse transcription reaction was carried out using equal quantities of total RNA $(1 \mu \mathrm{g})$ from each sample and Quanti Tect Reverse Transcription Kit (Qiagen ${ }^{\circledR}$ ). Electrophoresis using a $1.2 \%$ agarose gel was run to assess the quality of the RT-PCR product used for real-time quantitative PCR analyses of gene expression.

Differences in dietary-induced gene expression patterns in the intestine among groups were only compared between the control group (Diet A) and the experimental group displaying a greater increase in body weight and overall condition (Diet C). In this sense, we used a previously validated specific PCR-array of eighty-eight target genes ${ }^{(24)}$, this PCR-array was designed to cover different key biological functions: (i) cell differentiation and proliferation, $n$ 14; (ii) intestinal architecture and permeability, $n$ 20; (iii) enterocyte mass and epithelial damage, $n$ 9; (iv) IL and cytokines, $n$ 22; (v) pathogen recognition receptors, $n$ 14; and (vi) mitochondria function and biogenesis, $n 11$
(Table 2). Real-time quantitative PCR analysis of target genes was performed in eight specimens from Diets A and C using an iCycler IQ Real-time Detection System (Bio-Rad) as described in Pérez-Sánchez et $a l^{(24)}$. In brief, each PCR-well contained a SYBR Green Master Mix (Bio-Rad) and specific primers were used at a final concentration of $0.9 \mu \mathrm{m}$. DNA polymerase was activated and complementary DNA denatured by pre-incubation for $3 \mathrm{~min}$ at $95^{\circ} \mathrm{C}$, the template was amplified for forty cycles of denaturation for $15 \mathrm{~s}$ at $95^{\circ} \mathrm{C}$ and annealing/extension at $60^{\circ} \mathrm{C}$ for $60 \mathrm{~s}$. All pipetting operations were made with a handling robot (Eppendorf epMotion 5070) to minimise technical variability. $\beta$-Actin was chosen as a house keeping gene and no differences in gene expression were found between Diet A (control) and Diet C (experimental group) (cycle threshold $\left(C_{t}\right)$ values of $\beta$-actin: $19 \cdot 72 v$. 19.83). The efficiency of PCR reactions for all target and reference genes varied between 90 and $98 \%$. The dynamic range of standard curves (serial dilutions of RT-PCR reactions) spanned five orders of magnitude, and the amount of product in a particular sample was determined by interpolation of the $C_{t}$ value. The specificity of each reaction was verified by analysis of melting curves. Fluorescence data acquired during the extension phase were ultimately normalised to $\beta$-actin by the $\Delta \Delta C_{t}$ method $^{(25)}$

\section{Statistical analyses}

The mean values of $\mathrm{BW}_{f}, \mathrm{SL}_{f}$ and $K$ were expressed as means and standard deviations. The calculation was based on the values of the individual $\mathrm{BW}_{f}$, SL and $K$ of all the fish belonging to the same treatment (fish from the four tanks/replicate per dietary treatment analysed together, since there were no statistical differences between replicates), and consequently, the sD describes the dispersion of the individual values. In contrast, the mean values of survival, $\mathrm{BW}_{f}$ size classes, SGR, FCR, SFI, intestinal goblet cell number, villi width and height, and size of hepatic lipid vacuoles were calculated from each replicate tank $(n$ 4) and expressed as means with their standard errors. Data expressed as percentage were arcsine square root transformed before being analysed. Data were compared by means of one-way ANOVA (data normally distributed, Kolmogorov-Smirnov test) and comparisons between experimental groups after finding statistical significances were performed by a Bonferroni test. $C_{t}$ values between samples obtained from fish fed Diet A and $\mathrm{C}$ were compared by means of a $t$ test. Statistically significant differences were indicated by different letters. Data sets were analysed using the SigmaStat $3^{\circledR}$ software package (Systat Software Inc.).

\section{Results}

Survival, somatic growth performance and feed utilisation parameters

Data on survival, somatic growth performance in terms of $\mathrm{BW}_{f}$, $\mathrm{SL}_{f}$ and $K$, and feed utilisation parameters of gilthead sea bream fingerlings fed experimental diets are shown in Table 3. No differences in survival were found among experimental groups with mean values ranging between 96.0 and $97.5 \%$ 
Table 2. Full list of genes (abbreviation, gene name and accession number) analysed by real-time PCR in intestinal samples of gilthead sea bream (Sparus aurata) fed experimental diets containing different levels of a bioactive extract of olive oil

\begin{tabular}{|c|c|c|c|c|c|}
\hline Symbols & Gene names & $\begin{array}{l}\text { Accession } \\
\text { numbers }\end{array}$ & Symbols & Gene names & $\begin{array}{l}\text { Accession } \\
\text { numbers }\end{array}$ \\
\hline \multicolumn{3}{|c|}{ Cell differentiation and proliferation pathways } & \multicolumn{3}{|c|}{ IL and cytokines } \\
\hline Pcna & Proliferating cell nuclear antigen & KF857335 & $I / 1 \beta$ & IL 1 beta & CAD11603 \\
\hline Bmpr1a & $\begin{array}{l}\text { Bone morphogenetic protein } \\
\text { receptor type- } 1 \mathrm{~A}\end{array}$ & KF857333 & $1 / 1 r 1$ & IL 1 receptor type 1 & JX976615 \\
\hline Ihh & Indian hedgehog protein & KF857334 & $1 / 6$ & IL 6 & B6CKP4 \\
\hline Gli1 & Zinc finger protein GLI1 & KF857336 & $1 / 6 r b$ & IL 6 receptor subunit beta & JX976617 \\
\hline Hhip & Hedgehog-interacting protein & KF857338 & $1 / 7$ & IL 7 & JX976618 \\
\hline Wls & Protein wntless homolog & KF857339 & $1 / 8$ & IL 8 & JX976619 \\
\hline Myc & Transcriptional regulator Myc & KF857340 & II8ra & High affinity IL-8 receptor A & JX976620 \\
\hline Ctnnb1 & Catenin $\beta-1$ & KF857341 & $1 / 10$ & IL 10 & JX976621 \\
\hline Tcf4 & Transcription factor 4 & KF857342 & Il10ra & IL 10 receptor subunit alpha & JX976621 \\
\hline Nle1 & Notcheless protein homolog 1 & KF857343 & $/ 112 b$ & IL 12 B & JX976629 \\
\hline Hes1- $b$ & Transcription factor HES-1-B & KF857344 & Tnfa & TNFa & AJ413189 \\
\hline Gfi-1 & Zinc finger protein GFI-1 & KF857345 & Csf1r1 & $\begin{array}{l}\text { Macrophage colony-stimulating } \\
\text { factor } 1 \text { receptor } 1\end{array}$ & AM050293 \\
\hline Klf4 & Krueppel-like factor 4 & KF857346 & Cxcl9 & C-X-C motif chemokine 9 & KF857315 \\
\hline \multicolumn{3}{|c|}{ Intestinal architecture and permeability } & Ccl21 & C-C motif chemokine 21 & KF857316 \\
\hline $\operatorname{ltg} b 1 b p 1$ & Integrin $\beta$-1-binding protein 1 & KF861987 & Ccr3 & C-C chemokine receptor type 3 & KF857317 \\
\hline $\operatorname{ltg} 66$ & Integrin $\beta-6$ & KF861988 & $\operatorname{Ccr} 9$ & C-C chemokine receptor type 9 & KF857318 \\
\hline IIk & Integrin-linked protein kinase & KF861989 & Ccr11 & C-C chemokine receptor type 11 & KF857319 \\
\hline Ocln & Occludin & KF861990 & Ccl2O & C-C chemokine CK8 & GU181393 \\
\hline Cldn3 & Claudin 3 & KF861991 & $\mathrm{Cd48}$ & CD48 antigen & KF857320 \\
\hline Cldn12 & Claudin 12 & KF861992 & Cd276 & CD276 antigen & KF857321 \\
\hline Cldn15 & Claudin 15 & KF861993 & \multicolumn{3}{|c|}{ Pathogen recognition receptors } \\
\hline Tjp1 & Tight junction protein ZO-1 & KF861994 & TIr1 & Toll-like receptor 1 & KF857322 \\
\hline Cdh1 & Cadherin 1 & KF861995 & TIr2 & Toll-like receptor 2 & KF857323 \\
\hline Cdh17 & Cadherin 17 & KF861996 & TIr5 & Toll-like receptor 5 & KF857324 \\
\hline$F 11 r$ & Junctional adhesion molecule A & KF861997 & TIr9 & Toll-like receptor 9 & AY751797 \\
\hline Cxadr & $\begin{array}{l}\text { Coxsackievirus and adenovirus } \\
\text { receptor homolog }\end{array}$ & KF861998 & Nod1 & $\begin{array}{l}\text { Nucleotide-binding protein } \\
\text { oligomerisation domain- } \\
\text { containing protein } 1\end{array}$ & KF857325 \\
\hline$D s p$ & Desmoplakin & KF861999 & Mrc1 & Macrophage mannose receptor 1 & KF857326 \\
\hline$C \times 32.2$ & 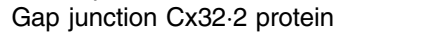 & KF862000 & Cd209 & CD209 antigen & KF857327 \\
\hline Gjb4 & Gap junction $\beta$-4 protein & KF862002 & Cd302 & CD302 antigen & KF857328 \\
\hline Muc2 & Mucin 2 & JQ27710 & Clec10a & $\begin{array}{l}\text { C-type lectin domain family } 10 \\
\text { member A }\end{array}$ & KF857329 \\
\hline MUC2-like & Mucin 2-like & JQ27711 & Lgals1 & Galectin-1 & KF862003 \\
\hline Muc13 & Mucin 13 & JQ27713 & Lgals8 & Galectin-8 & KF862004 \\
\hline I-muc & Intestinal mucin & JQ27712 & Csl2 & L-Rhamnose-binding lectin CSL2 & KF857330 \\
\hline \multicolumn{3}{|c|}{ Enterocyte function and epithelial damage } & $\mathrm{FCl}$ & Fucolectin & KF857331 \\
\hline Alpi & Intestinal-type alkaline phosphatase & KF857309 & Vim & Vimentin & KF857332 \\
\hline Fabp1 & Liver type fatty acid-binding protein & KF857311 & \multicolumn{3}{|c|}{ Mitochondria function and biogenesis } \\
\hline Fabp2 & Intestinal fatty acid-binding protein & KF857310 & Mthsp10 & $\begin{array}{l}\text { Mitochondrial } 10 \mathrm{kDa} \text { heat shock } \\
\text { protein }\end{array}$ & JX975224 \\
\hline Fabp6 & Ileal fatty acid-binding protein & KF857312 & Mthsp60 & $\begin{array}{l}\text { Mitochondrial } 60 \mathrm{kDa} \text { heat shock } \\
\text { protein }\end{array}$ & JX975227 \\
\hline Calr & Calreticulin & KF857313 & Mthsp70 & $\begin{array}{l}\text { Mitochondrial } 70 \mathrm{kDa} \text { heat shock } \\
\text { protein }\end{array}$ & DQ524993 \\
\hline Canx & Calnexin & KF857314 & Ech & Enoyl-CoA hydratase & JQ308826 \\
\hline Gr & Glutathione reductase & AJ937873 & Hadh & Hydroxyacyl-CoA dehydrogenase & JQ308829 \\
\hline Gst3 & Glutathione $S$-transferase 3 & JQ308828 & Cs & Citrate synthase & JX975229 \\
\hline Sod1 & $\begin{array}{l}\text { Superoxide dismutase }(\mathrm{Cu}-\mathrm{Zn}) \text {, } \\
\text { cytoplasmatic }\end{array}$ & JQ308833 & Tim44 & $\begin{array}{l}\text { Mitochondrial import inner } \\
\text { membrane translocase subunit } 44\end{array}$ & JX975239 \\
\hline Prdx1 & Peroxiredoxin 1 & GQ252679 & Tom22 & $\begin{array}{l}\text { Mitochondrial import receptor } \\
\text { subunit Tom } 22\end{array}$ & JX975236 \\
\hline Prdx2 & Peroxiredoxin 2 & GQ252680 & Mttfa & Mitochondrial transcription factor A & JX975262 \\
\hline \multicolumn{3}{|c|}{ House keeping gene } & Nrf1 & Nuclear respiratory factor 1 & JX975263 \\
\hline Actb & $\beta$-actin & X89920 & $P g c 1 a$ & $\begin{array}{l}\text { Proliferator-activated receptor } \gamma \\
\text { coactivator } 1 a\end{array}$ & JX975264 \\
\hline
\end{tabular}

(ANOVA, $P>0.05$ ). At the end of the trial, $\mathrm{BW}_{f}$ values were significantly different depending on the tested diet (ANOVA, $P<0.05)$. In this sense, fish fed Diets $C$ and D displayed the best values in $\mathrm{BW}_{f}$, those fed Diet A the lowest growth performance, whereas fish fed Diets B and E showed intermediate values.
On average, fish fed Diets $C$ and D were $5 \%$ heavier than those fed the other diets. Results in $\mathrm{BW}_{f}$ were supported by those from the distribution of $\mathrm{BW}_{f}$ size classes (Fig. 1). In brief, the greatest proportion of larger animals in terms of $\mathrm{BW}_{f}(61-80 \mathrm{~g})$ was observed among fish fed Diets C and D (51.7 (sE 0.9) and 
Table 3. Survival, growth performance in body weight $\left(\mathrm{BW}_{f}\right)$, standard length $\left(\mathrm{SL}_{f}\right)$, specific growth rate $(\mathrm{SGR})$ and Fulton's condition factor $(K)$, feed efficiency parameters (feed conversion ratio $(\mathrm{FCR})$ and specific feed intake (SFI)) and carcass chemical composition (in DM) of gilthead sea bream (Sparus aurata) fingerlings fed experimental diets containing different levels of a bioactive extract of olive-oil (Mean values and standard deviations)

\begin{tabular}{|c|c|c|c|c|c|c|c|c|c|c|}
\hline & \multicolumn{10}{|c|}{ Diets } \\
\hline & \multicolumn{2}{|c|}{ A } & \multicolumn{2}{|c|}{ B } & \multicolumn{2}{|c|}{ C } & \multicolumn{2}{|c|}{ D } & \multicolumn{2}{|c|}{ E } \\
\hline & Mean & SD & Mean & SD & Mean & SD & Mean & SD & Mean & SD \\
\hline Survival (\%)* & $96 \cdot 0$ & 0.6 & 97.3 & 0.4 & 97.0 & 0.3 & 97.5 & 0.5 & $96 \cdot 7$ & 0.4 \\
\hline $\mathrm{BW}_{(30 \mathrm{~d})}$ & $20 \cdot 2$ & 0.3 & $21 \cdot 2$ & 0.1 & 21.8 & 0.2 & 22.0 & 0.4 & 20.9 & 0.3 \\
\hline $\mathrm{BW}_{(60 \mathrm{~d})}$ & 39.2 & 0.3 & 41.0 & 0.3 & $42 \cdot 2$ & 0.6 & $42 \cdot 7$ & 0.4 & $40 \cdot 1$ & 0.6 \\
\hline $\mathrm{BW}_{\mathrm{f}(90 \mathrm{~d})} \dagger$ & $57 \cdot 0^{\mathrm{b}}$ & 0.7 & $58 \cdot 1^{a, b}$ & 1.5 & $61 \cdot 1^{\mathrm{a}}$ & 1.6 & $60 \cdot 3^{a}$ & $1 \cdot 1$ & $58 \cdot 8^{a, b}$ & 1.4 \\
\hline $\mathrm{SL}_{\mathrm{f}} \dagger$ & 11.8 & 0.2 & 11.8 & 0.2 & $12 \cdot 0$ & 0.2 & $12 \cdot 1$ & 0.1 & 11.8 & 0.1 \\
\hline $\mathrm{K}+$ & 3.5 & 0.08 & 3.6 & 0.02 & 3.5 & 0.05 & 3.4 & 0.03 & 3.6 & 0.15 \\
\hline $\mathrm{SGR}_{(0-90 \mathrm{~d})}(\% / \mathrm{d})^{*}$ & $2 \cdot 60$ & 0.02 & $2 \cdot 62$ & 0.06 & $2 \cdot 67$ & 0.03 & 2.67 & 0.03 & 2.63 & 0.02 \\
\hline $\mathrm{FCR}^{\star}$ & 1.06 & 0.01 & 1.07 & 0.01 & 1.05 & 0.01 & 1.06 & 0.01 & 1.06 & 0.01 \\
\hline $\mathrm{SFI}^{*}$ & $2 \cdot 76$ & 0.02 & $2 \cdot 77$ & 0.02 & $2 \cdot 83$ & 0.02 & 2.78 & 0.02 & $2 \cdot 78$ & 0.02 \\
\hline \multicolumn{11}{|l|}{ Carcass compositionł } \\
\hline Protein (\%) & 66.9 & 2.5 & $68 \cdot 7$ & 3.3 & $69 \cdot 3$ & 1.0 & $70 \cdot 0$ & $2 \cdot 7$ & $66 \cdot 8$ & 1.0 \\
\hline Lipid (\%) & $12 \cdot 3$ & 1.0 & 13.6 & 0.8 & 13.6 & 0.9 & 14.7 & 0.4 & $12 \cdot 6$ & 0.8 \\
\hline Ash (\%) & $2 \cdot 1$ & 0.2 & $2 \cdot 1$ & 0.2 & 2.1 & 0.2 & 2.0 & 0.1 & 2.0 & 0.1 \\
\hline Lipid liver contentł & $17 \cdot 1$ & 0.7 & 17.9 & 0.7 & 18.7 & 1.5 & 18.8 & 1.9 & 18.9 & 1.5 \\
\hline
\end{tabular}

a,b Mean values within rows with unlike superscript letters denote significant differences between dietary groups (ANOVA, $P<0.05)$

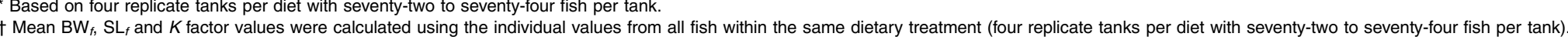
₹ Based on twenty fish per diet (four replicate tanks per diet with five randomly selected fish per tank). 

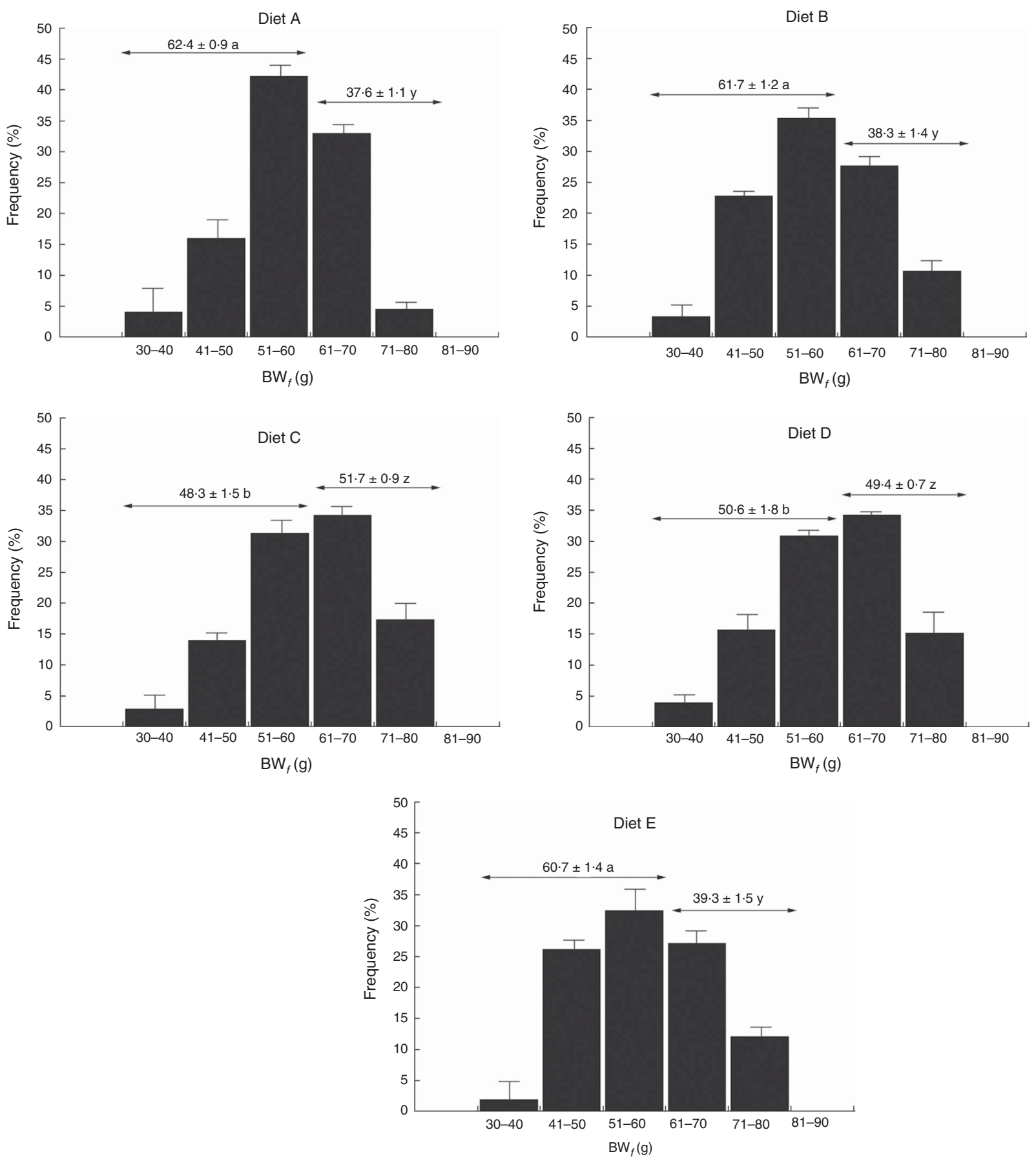

Fig. 1. Distribution of final body weight $\left(B W_{f}\right)$ of gilthead sea bream (Sparus aurata) fed experimental diets containing different levels of a bioactive extract of olive oil. Values are mean frequencies for each size category calculated, with their standard errors, from all fish from each replicate. ${ }^{\text {a,b,y,z }}$ Mean values with unlike letters denote differences among dietary groups $(P<0.001)$.

$49 \cdot 4$ (se $0 \cdot 7) \%$, respectively), whereas it was only $37 \cdot 6$ (se $1 \cdot 1$ ), 38.3 (SE 1.4) and 39.3 (se 1.5)\% in fish fed Diets A, B and E, respectively (ANOVA, $P<0.05$ ). However, there were no statistically significant differences in SGR values among groups (ANOVA, $P>0.05$ ). In addition, $\mathrm{SL}_{f}$ and $K$ values were similar among different experimental groups (ANOVA, $P>0.05$ ), and no differences in FCR and SFI were found among groups fed different diets (ANOVA, $P>0.05$ ).
Carcass proximate composition, hepatic fat content, and lipid peroxidation and antioxidative stress enzymes in liver and intestine

There were no differences in the carcass composition and hepatic fat content among fish fed experimental diets (ANOVA, $P>0.05$; Table 3 ). There were no statistically significant differences in LPO levels and activity of CAT, GR and 
GST in the intestine and liver of gilthead sea bream fed different diets (ANOVA, $P>0.05$; Table 4 ).

\section{Histological organisation of the intestinal mucosa and liver}

In all experimental groups, the intestine was lined by a simple columnar epithelium with basal nuclei, basophilic cytoplasm and prominent microvilli. The organisation of the lamina propria, submucosa and tunica muscularis was normal. No lipid deposits were found either within enterocytes or in the vascular system, indicating that the lipid content in tested diets did not imbalance the absorptive and transporting lipid capacities of the intestine (online Supplementary Fig. S2). No differences in villus size, width and height were found among treatments (Table 4), whereas the number of intestinal goblet cells was significantly affected by the presence of OBE in the diet (ANOVA, $P<0 \cdot 001$; Table 5). In this sense, goblet cell density in fish fed Diet A ( 1.8 (sE 0.05 ) goblet cells in $100 \mu \mathrm{m}$ of intestinal epithelium) was on average $14.3 \%$ lower than in fish fed diets containing OBE (treatment mean $=2 \cdot 1 \quad$ (SE 0.05$)$ goblet cells in $100 \mu \mathrm{m}$ of intestinal epithelium).

Under present experimental conditions, the histological organisation of the liver was normal, with hepatocytes arranged along sinusoids. In any case, hepatic steatosis (severe fat accumulation in hepatocytes affecting their integrity and functionality) was not observed in any of the examined fish. Data on the semiquantitative evaluation of lipid accumulation in hepatocytes of gilthead sea bream fed experimental diets are shown in Table 5. In general terms, fish showed similar levels of hepatic fat accumulation within hepatocytes (online Supplementary Fig. S2); however, the size of lipidic vacuoles and the level of peripheral displacement of nuclei within hepatocytes was slightly lower in fish fed Diets C and D in comparison to the control group (Diet A), whereas the rest of groups showed intermediate values.

\section{Intestinal gene expression profiling}

The $C_{t}$ values for all the target genes analysed in this study with regard to the effect of supplementing the diet $\mathrm{C}$ with OBE on the integrity and health of the intestine are shown in the online Supplementary Table S1. Among the eighty-eight genes evaluated, twenty-nine were differentially expressed in response to the presence of OBE in the diet (Table $6 ; t$ test, $P<0 \cdot 05$ ). Among the thirteen studied genes related to cell differentiation and proliferation, four of them were significantly affected by the diet. In particular, proliferating cell nuclear antigen (Pcna) was the only one down-regulated, whereas bone morphogenetic protein receptor type-1A (Bmpr1a), transcription factor 4 (Tcf4) and Krueppel-like factor 4 (Klf4) were up-regulated in fish fed the OBE diet. Six of the sixteen genes analysed related to intestinal architecture and permeability were up-regulated (occludin $(\mathrm{Ocln}), \mathrm{Cldm} 3$, claudin 12 (Cldn12), junctional adhesion molecule A (F11r), coxsackievirus and adenovirus receptor homolog (Cxadr) and desmoplakin (Dsp)), whereas the rest of them were not affected by the diet. The expression of calreticulin (Calr) decreased, whereas that of three of the nine genes studied involved in enterocyte function and epithelial damage were up-regulated (intestinal-type alkaline phosphatase (Alpi), liver type fatty acid-binding protein $(F a b p 1)$ and $G r$ ). Almost half of the genes coding for IL and cytokines were differentially expressed (10/22); in particular, Il1r1, Il6rb, Il8, Il10ra, Il12b, Tnfo, Csf1r1, Ccr9 and Ccr11 were up-regulated, whereas $I l 7$ was down-regulated. Among the fourteen pathogen recognition receptor genes analysed, four of them (Toll-like receptor 2 ( Tlr2), nucleotide-binding protein oligomerisation domain-containing protein 1 (Nod1), CD302 antigen (Cd302) and fucolectin $(F C l)$ ) were up-regulated in the intestinal mucosa of fish fed the OBE diet. Regarding the expression of genes related to mitochondria function and biogenesis, molecular chaperones (mitochondrial $10 \mathrm{kDa}$ heat shock protein ( $m$ tHsp10), mitochondrial $60 \mathrm{kDa}$ heat shock protein ( $m t H s p 60)$ ) and membrane protein translocases (mitochondrial import inner membrane translocase subunit 44 (Tim44), mitochondrial import receptor subunit Tom 22 (Tom22)) were down-regulated in fish fed the OBE diet, whereas an opposite pattern was found for the transcription factor $P g c 1$.

\section{Discussion}

Previous studies dealing with the inclusion of bioactive compounds derived from olive oil in aqua feeds have been mostly limited to maslinic acid. In particular, it has been shown that a diet supplemented with maslinic acid $(250 \mathrm{mg} / \mathrm{kg}$ feed) promoted growth in Oncorbynchus mykiss ${ }^{(9)}$, whereas similar or lower levels $(100 \mathrm{mg} / \mathrm{kg}$ feed) of this triterpenic compound did not affect growth performance in gilthead sea bream ${ }^{(10,11)}$, even though it enhanced hepatic protein-turnover rates ${ }^{(10)}$ and induced hypertrophy in muscle fibres were found ${ }^{(11)}$. In addition, no effect on growth performance in Dentex dentex was observed when using higher doses of maslinic acid (20, 40, $80 \mathrm{~g} / \mathrm{kg}$ feed) ${ }^{(26)}$. Under present experimental conditions, the inclusion of OBE slightly enhanced growth independently of feed intake without affecting neither feed efficiency parameters nor the proximate composition of the fillet. The effect of OBE on growth in body weight was not-linear, as the highest mean values of $\mathrm{BW}_{f}$ were observed in fish fed 0.17 and $0.42 \%$ of OBE and not in those fed the highest inclusion of OBE in diets $(0.73 \%)$, which indicated a quadratic growth response to OBE inclusion in diets for gilthead sea bream. In addition, the inclusion of OBE in diets affected the final fish size distribution in $\mathrm{BW}$, resulting in a more homogeneous fish size distribution in those groups fed the OBE diets, although the rationale of these findings with regard to the administered diet needs to be further investigated. However, these findings are of practical importance since the use of $\mathrm{OBE}$ in diets might reduce the effort required for size selection during processing of production lots, and also in a reduction of hierarchical dominance situations ${ }^{(27,28)}$. Although these results might be partially attributed to the potential growth-promoting effect of polyphenols ${ }^{(29)}$, our data suggest that they were most likely related to the enhancement of the health condition of the intestinal mucosa as described below.

The intestine is involved not only in digestion and feed absorption but also in water and electrolyte balance, nutrient sensing and immunity ${ }^{(30)}$. This functional diversity is now 
Table 4. Levels of lipid peroxidation (LPO) and catalase (CAT), glutathione reductase (GR) and glutathione S-transferase (GST) from the intestine and liver of gilthead sea bream (Sparus aurata) fed experimental diets containing different levels of a bioactive extract of olive oil

(Mean values with their standard errors; $n$ )

\begin{tabular}{|c|c|c|c|c|c|c|c|c|c|c|}
\hline \multirow[b]{3}{*}{ Intestine } & \multicolumn{10}{|c|}{ Diets } \\
\hline & \multicolumn{2}{|c|}{ A } & \multicolumn{2}{|c|}{$B$} & \multicolumn{2}{|c|}{ C } & \multicolumn{2}{|c|}{$D$} & \multicolumn{2}{|c|}{$E$} \\
\hline & Mean & SE & Mean & SE & Mean & SE & Mean & SE & Mean & SE \\
\hline LPO (nmol MDA mg/protein) & 1.44 & 0.14 & 1.30 & 0.01 & 1.20 & 0.02 & 1.23 & 0.19 & 1.03 & 0.05 \\
\hline CAT (nmol/mg protein) & 2694 & $350 \cdot 4$ & $2490 \cdot 1$ & 441.4 & $2135 \cdot 1$ & 223.1 & $1981 \cdot 6$ & $252 \cdot 2$ & $2376 \cdot 7$ & $219 \cdot 6$ \\
\hline GR (nmol/mg protein) & $12 \cdot 14$ & 0.54 & 13.26 & 1.62 & $13 \cdot 12$ & 0.23 & 13.63 & 1.05 & 11.54 & 0.38 \\
\hline GST (nmol/mg protein) & $28 \cdot 41$ & $4 \cdot 30$ & 27.90 & $4 \cdot 20$ & $27 \cdot 56$ & 4.95 & $26 \cdot 57$ & $2 \cdot 37$ & $28 \cdot 23$ & 2.94 \\
\hline \multicolumn{11}{|l|}{ Liver } \\
\hline LPO (nmol MDA mg/protein) & 1.44 & 0.15 & $1 \cdot 30$ & 0.01 & 1.20 & 0.02 & 1.23 & $0 \cdot 19$ & 1.28 & 0.07 \\
\hline CAT (nmol/mg protein) & 923.5 & $125 \cdot 9$ & $857 \cdot 3$ & $235 \cdot 3$ & $865 \cdot 3$ & $148 \cdot 2$ & $927 \cdot 6$ & $65 \cdot 2$ & $868 \cdot 2$ & $322 \cdot 1$ \\
\hline GR (nmol/mg protein) & $17 \cdot 72$ & 0.58 & 12.75 & 1.60 & 11.34 & 2.09 & $12 \cdot 74$ & 1.27 & $12 \cdot 64$ & 1.98 \\
\hline GST (nmol/mg protein) & 16.09 & $2 \cdot 17$ & 12.07 & 0.87 & 13.09 & 1.95 & $13 \cdot 47$ & 1.86 & 13.89 & 0.97 \\
\hline
\end{tabular}

MDA, malondialdehyde.

Table 5. Size of hepatic lipid deposits $\left(\mu \mathrm{m}^{2}\right)$, villi size in height and width $(\mu \mathrm{m})$ and goblet cell density (number of goblet cells in $100 \mu \mathrm{m}$ of epithelium) in the intestine of gilthead sea bream (Sparus aurata) fed experimental diets with different levels of an olive oil bioactive extract

(Mean values with their standard errors; $n$ )

\begin{tabular}{|c|c|c|c|c|c|c|c|c|c|c|}
\hline & \multicolumn{10}{|c|}{ Diets } \\
\hline & \multicolumn{2}{|c|}{ A } & \multicolumn{2}{|c|}{ B } & \multicolumn{2}{|c|}{ C } & \multicolumn{2}{|c|}{ D } & \multicolumn{2}{|c|}{ E } \\
\hline & Mean & SE & Mean & SE & Mean & SE & Mean & SE & Mean & SE \\
\hline Hepatic lipid vacuoles' size & $133 \cdot 1^{b}$ & 7.5 & $115 \cdot 9^{a, b}$ & $10 \cdot 9$ & $86.6^{a}$ & $9 \cdot 8$ & $89.9^{a}$ & 3.5 & $104 \cdot 9^{a, b}$ & 5.4 \\
\hline Villus height & $1273 \cdot 8$ & $68 \cdot 3$ & $1330 \cdot 6$ & 50.5 & 1452 & $36 \cdot 6$ & 1457 & 49.5 & 1390 & 48.5 \\
\hline Villus width & 287.5 & $45 \cdot 6$ & 297.4 & 65.4 & 291.9 & 41.9 & 311.4 & $51 \cdot 1$ & 294.5 & 34.8 \\
\hline Goblet cell density & $1.80^{\mathrm{b}}$ & 0.06 & $2 \cdot 17^{\mathrm{a}}$ & 0.14 & $2 \cdot 17^{\mathrm{a}}$ & 0.13 & $2 \cdot 20^{\mathrm{a}}$ & 0.11 & $2 \cdot 26^{\mathrm{a}}$ & 0.10 \\
\hline
\end{tabular}

${ }_{a, b}$ Mean values within rows with unlike superscript letters denote significant differences between dietary treatments (ANOVA, $P<0.05$ ). 
Table 6. Differentially expressed genes (Student $t$ test, $P<0.05$ ) in the intestine of fish fed the control (Diet $A$ ) and Diet $C$ containing $1.7 \mathrm{~g}$ olive oil bioactive extract per $\mathrm{kg}_{\text {feed }}{ }^{*}$

(Mean values with their standard errors; $n$ 8)

\begin{tabular}{|c|c|c|}
\hline \multirow[b]{2}{*}{ Genes } & \multicolumn{2}{|c|}{ Fold change } \\
\hline & Mean & SE \\
\hline \multicolumn{3}{|c|}{ Cell differentiation and proliferation (4) } \\
\hline Pcna & 0.54 & 0.11 \\
\hline Bmpr1a & 1.50 & 0.11 \\
\hline Tcf4 & 1.68 & 0.16 \\
\hline Klf4 & 1.55 & 0.15 \\
\hline \multicolumn{3}{|c|}{ Intestinal architecture and permeability (6) } \\
\hline Ocln & 2.47 & 0.26 \\
\hline Cldn3 & 1.49 & 0.18 \\
\hline Cldn12 & 1.36 & 0.13 \\
\hline F11r & 1.27 & 0.08 \\
\hline Cxadr & 1.38 & 0.11 \\
\hline$D s p$ & 1.87 & 0.19 \\
\hline \multicolumn{3}{|c|}{ Enterocyte mass and epithelia damage (4) } \\
\hline Alpi & 1.68 & 0.20 \\
\hline Fabp1 & 1.26 & 0.08 \\
\hline Calr & 0.64 & 0.08 \\
\hline Gr & 1.38 & 0.14 \\
\hline \multicolumn{3}{|c|}{$\mathrm{IL}$ and cytokines (10) } \\
\hline$\| 1 r 1$ & $2 \cdot 18$ & 0.33 \\
\hline$\| 6 r b$ & 1.39 & 0.14 \\
\hline 117 & 0.81 & 0.05 \\
\hline 118 & 1.81 & 0.25 \\
\hline Il10ra & 1.48 & 0.15 \\
\hline $1 / 12 b$ & 1.71 & 0.20 \\
\hline Tnfa & 1.60 & 0.19 \\
\hline Csf1r1 & 1.42 & 0.10 \\
\hline Ccr9 & 1.57 & 0.12 \\
\hline Ccr11 & 3.77 & 0.65 \\
\hline \multicolumn{3}{|c|}{ Pathogen recognition receptors (4) } \\
\hline TIr2 & 1.34 & 0.10 \\
\hline Nod1 & 1.61 & 0.11 \\
\hline Cd302 & 1.53 & 0.15 \\
\hline $\mathrm{FCl}$ & 3.14 & 0.52 \\
\hline \multicolumn{3}{|c|}{ Mitochondria function and biogenesis (5) } \\
\hline$m t H s p 10$ & 0.49 & 0.05 \\
\hline$m t H s p 60$ & 0.48 & 0.04 \\
\hline Tim44 & 0.71 & 0.04 \\
\hline Tom22 & 0.78 & 0.06 \\
\hline Pgcla & 1.74 & 0.19 \\
\hline
\end{tabular}

Pcna, proliferating cell nuclear antigen; Bmpr1a, bone morphogenetic protein receptor type 1A; Tcf4, transcription factor 4; Klf4, Krueppel-like factor 4; Ocln, occluding; Cldn3, claudin 3; Cldn12, claudin 12; F11r, junctional adhesion molecule A; Cxadr, coxsackievirus and adenovirus receptor homolog; Dsp, desmoplakin; II1r1, IL 1 receptor type 1; I/6rb, IL 6 receptor subunit $\beta$; I/10ra, IL 10 receptor subunit $a$; Csf1r1, macrophage colony-stimulating factor 1 receptor 1; Ccr9, C-C chemokine receptor type 9; Ccr11, C-C chemokine receptor type 11; TIr2, toll-like receptor 2; Nod1, nucleotide-binding protein oligomerisation domain-containing protein 1; Cd302, CD302 antigen; Fcl, fucolectin; Mthsp10, mitochondrial $10 \mathrm{kDa}$ heat shock protein; Mthsp60, mitochondrial $60 \mathrm{kDa}$ heat shock protein; Tim44, mitochondrial import inner membrane translocase subunit 44; Tom22, mitochondrial import receptor subunit Tom 22.

* Values $>1$ are up-regulated genes in fish fed Diet $C$. Values $<1$ are down-regulated genes in fish fed Diet C.

starting to be elucidated in fish and different histological and molecular approaches are helping to understand the many vital functions conducted along the gastrointestinal tract ${ }^{(31,32)}$. The inclusion of $\mathrm{OBE}$ in the diet resulted in an increase of the goblet cell population in the intestinal epithelium. This histological observation was supported by the up-regulated expression of the zinc-finger transcription factor $K l f 4$, a goblet-cell specific intestinal differentiation factor ${ }^{(33)}$. The increase in goblet cell number would benefit fish by providing an effective immune barrier against potentially pathogenic gut bacteria ${ }^{(34)}$, which also agrees with an enhanced expression of several pathogen recognition receptors (Tlr2, Nod1, Cd3O2, Fcl). In higher vertebrates, it has been demonstrated that TLR4- and TLR2-dependent pathways can stimulate $\beta$-defensin- 2 expression by intestinal epithelial cells that are able to respond to pathogen-associated molecular patterns (PAMP) by secreting antimicrobial peptides, as well as protecting the epithelium from injuries ${ }^{(35)}$ and reducing intestinal permeability by protecting tight junctions ${ }^{(36)}$. In addition, NOD1-mediated innate immune responses are critically involved in the intestinal homoeostasis of higher vertebrates ${ }^{(35)}$, where epithelial cells remain responsive to invasive bacteria via ligand binding to NOD1 or NOD2 ${ }^{(36)}$. Similarly, the CD3O2 gene encodes for a C-type lectin receptor involved in cell adhesion and migration, as well as in endocytosis and phagocytosis processes $^{(37)}$. It is noteworthy that the highest fold change in expression among pathogen recognition receptors was found in $\mathrm{fcl}$, a gene coding for fucolectin that has been described to enhance phagocytosis in in vitro studies with peritoneal macrophages in Dicentrarchus labrax ${ }^{(38)}$.

The inclusion of the OBE in the diet affected gene expression of approximately half of the IL and cytokines analysed in this study. The up-regulation of a vast array of pathogen recognition receptors and pro-inflammatory IL, IL receptors and cytokines (Il1r1, Il6r $\beta$, Il12, Ils, Tnfo, Csf1r1, Ccr9 and Ccr11) highly supports an immunostimulatory action ${ }^{(39)}$ of OBE when included at $0 \cdot 17 \%$ of the diet. Early elimination of potential pathogens has clear implications for improved health, but also for the bioenergenetic balance of the whole animal; much less energy is expended when pathogens are removed before they have opportunities for proliferation. Further, the enhanced mucin production due to increased goblet cell populations provides a physical displacement of potential pathogenic organisms; a more diverse microbiota leads to a thickening of the mucus layer and this improves the microniches of the gut inhabited by these beneficial bacteria ${ }^{(40)}$. In this sense, further research is needed to evaluate the potential effects of OBE in modulating the microbiota.

The homoeostasis of the constantly renewing intestinal epithelium relies on an integrated control of proliferation, differentiation and apoptosis, as well as on the functional architecture of the epithelial cells. Thus, the down-regulation of pcna in fish fed OBE at $0 \cdot 17 \%$ of the diet in comparison to the control group might be attributed to lower epithelial turnover rate associated with a better health condition of enterocytes, which was in agreement with the higher transcription of the bmpr1a that codes for the bone morphogenetic protein receptor, type $1 \mathrm{~A}$ that plays a major role in cell differentiation. This hypothesis is supported by the up-regulation of Tcf4 in this group of fish, as this transcription factor is a key player in the Wnt pathway signalling and maintaining the homoeostasis of the intestinal epithelium $^{(41)}$. However, BMPR1A inhibits WNT signalling. Thus, although both inhibitory (Bmpr1a) and stimulatory (Tcf4) signals of stem cell proliferation were up-regulated by the OBE diet, the net result would be prone to promote cell differentiation rather than cell proliferation. 
Enhanced terminal cell differentiation would have a variety of potentially beneficial consequences, but one possible is the observed increase in goblet cells. Prevention of the entrance of toxic molecules or infectious agents, such as solutes, antigens and micro-organisms, is ensured by the gastrointestinal mucosa. A key structure of the intercellular space is the tight junction, which plays a major role in regulating the paracellular passage of luminal elements. Therefore, proper functioning and regulation of tight junctions is crucial. These junctions are under the influence of intestinal microflora, inflammation and even alimentary components, which can compromise tight junctions ${ }^{(42)}$. Three of the main protein families found in tight junctions are occludins, claudins and junction-associated membrane proteins ${ }^{(43)}$. In particular, OBE may reduce intestinal permeability and consequently, the risk of intestinal disorders by increasing the expression of genes coding for mucosal tight junction proteins like occludin, claudin 3 and 12, and F11 receptor, the so-called junctional adhesion molecule $\mathrm{A}$, as well as desmoplakin that is involved in maintaining the desmosome structure.

In addition, the inclusion of OBE at $0 \cdot 17 \%$ in the diet improved the condition of enterocytes by reducing the expression of several gene markers related to mitochondrial function (mtHsp10, mtHsp60, Tim44, Tom22). In particular, TOM22 and TIM44 proteins are involved in the translocation of transit peptide-containing proteins from the outer and inner mitochondrial membranes ${ }^{(44,45)}$, whereas PGC1 $\alpha$ is a transcriptional co-activator that is involved in controlling global oxidative metabolism by regulating mitochondrial biogenesis and function $^{(46)}$. Furthermore, OBE induced the down-regulation of $m t H s p 60$ and $m t H s p 10$, two genes encoding for $\mathrm{UPR}^{\mathrm{mt}}$ responsive proteins that are involved in protein homoeostasis in mitochondria ${ }^{(47)}$. Thus, the down-regulation of the abovementioned genes coupled with the increase in expression of pgc1 $\alpha$ may correlate with a lower metabolic rate of mitochondria, protein turnover and potentially lower oxidative stress in the intestinal mucosa of fish fed the OBE diet ${ }^{(48)}$. Indeed, this suggestion is in line with the tendency found for fish fed the OBE diets to show lower LPO values $(P=0.091)$ in comparison with the control group.

Regarding the expression of genes involved in enterocytes' function and epithelial damage, $45 \%$ of the analysed genes were differentially expressed when fish were fed the diet containing OBE at $0.17 \%$ of the diet. In particular, Alpi regulates lipid absorption across the apical membrane of enterocytes, participates in the regulation of bicarbonate secretion and duodenal surface $\mathrm{pH}$, limits bacterial transepithelial passage and finally protects against bacterial endotoxin-induced inflammation by dephosphorylating lipopolysaccharides ${ }^{(30)}$. Thus, the up-regulation of Alpi may indicate a more mature enterocyte in fish fed the OBE diet ${ }^{(49)}$, as well as reinforce the idea of an enhanced intestinal immune function ${ }^{(28)}$. In addition, the higher expression of Alpi and Fabp1 might be related to their role in fatty acid uptake from the lumen of the intestine and trafficking within the enterocyte ${ }^{(50)}$. CALR is reported to play a role in many cellular functions including lectin-like chaperoning, $\mathrm{Ca}^{2+}$ storage and signalling, regulation of gene expression, cell adhesion, wound healing and autoimmunity ${ }^{(51,52)}$; thus, the down-regulation of Calr in fish fed the OBE diet is in agreement with the proposed decrease in intestinal epithelial permeability and overall improvement of intestinal health, as it has been recently reported in Ictalurus punctatus ${ }^{(53)}$.

Regarding the impact of the feed additive on the liver, present results revealed that the inclusion of OBE reduced the size of hepatic deposits within hepatocytes, which may be in agreement with the tendency for lower LPO values in the liver of fish fed diets containing OBE. These results were in agreement with in vitro ${ }^{(54)}$ and in vivo ${ }^{(55)}$ models that have shown that polyphenols reduce hepatocellular lipid accumulation by means of the regulation of the AMP-activated protein kinase signalling and hepatocyte lipid metabolism. In addition, triterpenic acids have been also reported to be involved in regulating hepatic lipid accumulation and reducing hepatic steatosis ${ }^{(56)}$, stimulating liver protein-synthesis rates ${ }^{(9)}$, as well as regulating proteins involved in liver metabolism and detoxification processes ${ }^{(57-59)}$. However, further research is needed in fish model species in order to properly characterise by means of transcriptomic and physiological approaches the impact of OBE in the health condition and metabolism of the liver, especially in fish fed diets with a high level of fish oil substituted by vegetal oil sources.

\section{Conclusions}

The inclusion of OBE in the diet had a positive effect on growth performance in gilthead sea bream juveniles. This effect depended on the dose, becoming significant when OBE was included at 0.17 and $0.42 \%$ of the diet. The inclusion of OBE reduced the size of hepatic deposits within hepatocytes, which may be in agreement with the tendency for lower LPO values in the liver of fish fed diets containing OBE, suggesting that $\mathrm{OBE}$ may positively affect lipid metabolism in the liver and potentially prevent hepatic steatosis. Results from the transcriptomic profiling of the intestine suggested that OBE enhanced fish growth primarily by improving the condition and defensive role of the intestine. When OBE was fed at $0 \cdot 17 \%$ of the diet such a response appeared to involve augmented enterocytes' maturation, increased integrity of the intestinal epithelium and goblet cell density, and improved intestinal innate immune function, as gene-expression data indicated. These results showed that OBE is a promising feed additive for the aquaculture industry with multiple beneficial properties.

\section{Acknowledgements}

The authors express their gratitude to S. Molas, M. Sastre and O. Bellot IRTA for their assistance during the trial, and biochemical and histological analyses, respectively. The authors are grateful to M. A. González (CSIC) for assistance in PCR analyses.

This study was funded by the 'Ministerio de Economía y Competitividad' (MINECO) from the Government of Spain (project BIOADA, reference no. RTC-2014-2018-2).

Conceived and designed the experiments: J. C. Q., E. G. Analysed the data: J. P.-S., E. G., K. B. A., J. A. C.-G. Fish husbandry and fish sampling: E. G., K. B. A. Manuscript preparation: J. C. Q., J. P.-S., E. G., K. B. A., J. A. C.-G., I. R. I.

The authors declare that there are no conflicts of interest. 


\section{Supplementary material}

For supplementary material/s referred to in this article, please visit https://doi.org/10.1017/S0007114517000228

\section{References}

1. Sofi F, Abbate R, Gensini GF, et al. (2010) Accruing evidence on benefits of adherence to the Mediterranean diet on health: an updated systematic review and meta-analysis. Am J Clin Nutr 92, 1189-1196.

2. Owen RW, Giacosa A, Hull WE, et al. (2000) Olive-oil consumption and health: the possible role of antioxidants. Lancet Oncol 1, 107-112.

3. Covas MI, Ruiz-Gutiérrez V, De La Torre R, et al. (2006) Minor components of olive oil: evidence to date of health benefits in humans. Nutr Rev 64, S20-S30.

4. Ghanbari R, Anwar F, Alkharfy KM, et al. (2012) Valuable nutrients and functional bioactives in different parts of olive (Olea europaea L.) - a review. Int J Mol Sci 13, 3291-3340.

5. Sánchez- Quesada C, López-Biedma A, Warleta F, et al. (2013) Bioactive properties of the main triterpenes found in olives, virgin oil, and leaves of Olea europaea.J Agric Food Chem $\mathbf{6 1}$, 12173-12182.

6. Omar SH (2010) Oleuropein in olive and its pharmacological effects. Sci Pharm 78, 133-154.

7. Caramia G, Gori A, Valli E, et al. (2012) Virgin olive oil in preventive medicine: from legend to epigenetics. Eur J Lipid Sci Technol 114, 375-388.

8. Naylor RL, Hardy RW, Bureau DP, et al. (2009) Feeding aquaculture in an era of finite resources. Proc Natl Acad Sci U $S$ A 106, 15103-15110.

9. Fernández-Navarro M, Peragón J, Esteban FJ, et al. (2006) Maslinic acid as a feed additive to stimulate growth and hepatic protein-turnover rates in rainbow trout (Onchorbynchus mykiss). Comp Biochem Physiol C Toxicol Pharmacol 144, 130-140.

10. Rufino-Palomares EE, Reyes-Zurita FJ, García-Salguero L, et al. (2012) Maslinic acid, a natural triterpene, and ration size increased growth and protein turnover of white muscle in gilthead sea bream (Sparus aurata). Aquac Nutr 18, 568-580.

11. Matos E, Silva T, Wulff T, et al. (2013) Influence of supplemental maslinic acid (olive-derived triterpene) on the post-mortem muscle properties and quality traits of gilthead seabream. Aquaculture 396-399, 146-155.

12. European Aquaculture Technology and Innovation Platform (2012) The future of European aquaculture. http://www.eatip. eu/default.asp?SHORTCUT=92 (accessed May 2016).

13. Oliva-Teles A, Lpatsch I \& Nengas I (2011) Nutrition and feeding of Sparidae. In Sparidae: Biology and Aquaculture of Gilthead Sea Bream and Other Sparidae, pp 199-232 [MA Pavlidis and CC Mylonas, editors]. Oxford: Blackwell Publishing Ltd.

14. Folch J, Lees N \& Sloane-Stanley GH (1957) A simple method for the isolation and purification of total lipids from animal tissues. J Biol Chem 226, 497-509.

15. Lowry $\mathrm{OH}$, Rosebrough NJ, Farr AL, et al. (1951) Protein measurement with the Folin phenol reagent. J Biol Chem 193, 265-275.

16. Association of Official Analytical Chemists (1990) In Official Methods of Analysis of the Association of Official Analytical Chemists, pp. 69-90, [K Heldrich, editor]. Arlington, VA: AOAC.

17. Solé M, Potrykus J, Fernández-Díaz C, et al. (2004) Variations on stress defences and metallothionein levels in the Senegal sole, Solea senegalensis, during early larval stages. Fish Physiol Biochem 30, 57-66.
18. Aebi H (1974) Catalase. In Methods in Enzymatic Analysis vol. 2, pp. 674-684 [HV Bergmeyer, editor]. New York: Academic Press Inc.

19. Habig WH, Pabst MJ \& Jakoby WB (1974) Glutathione $S$-transferases the first enzymatic step in mercapturic acid formation. J Biol Chem 249, 7130-7139.

20. Carlberg I \& Mannervik B (1975) Purification and characterization of the flavoenzyme glutathione reductase from rat liver. J Biol Chem 250, 5475-5480.

21. Bradford MM (1976) A rapid and sensitive method for the quantitation of microgram quantities of protein utilizing the principle of protein-dye binding. Anal Biochem 72, 248-254.

22. Escaffre AM, Kaushik S \& Mambrini M (2007) Morphometric evaluation of changes in the digestive tract of rainbow trout (Oncorbynchus mykiss) due to fish meal replacement with soy protein concentrate. Aquaculture 273, 127-138.

23. Darias MJ, Gómez MA, Tello S, et al. (2015) Growth, survival and the histology of the digestive tract of juvenile Osteoglossum bicirrbosum (Cuvier, 1829) fed three diets containing different protein and lipid levels. J Appl Ichthyol 31, 67-73.

24. Pérez-Sánchez J, Benedito-Palos L, Estensoro I, et al. (2015) Effects of dietary NEXT ENHANCE ${ }^{\circledR} 150$ on growth performance and expression of immune and intestinal integrity related genes in gilthead sea bream (Sparus aurata L.). Fish Shellfish Immunol 44, 117-128.

25. Livak KJ \& Schmittgen TD (2001) Analysis of relative gene expression data using real-time quantitative PCR and the $2-\Delta \Delta$ CT method. Methods 25, 402-408.

26. Hidalgo MC, Skalli A, Abellán E, et al. (2006) Dietary intake of probiotics and maslinic acid in juvenile dentex (Dentex dentex L.): effects on growth performance, survival and liver proteolytic activities. Aquac Nutr 12, 256-266.

27. Petursdottir TE (2002) Influence of feeding frequency on growth and size dispersion in Arctic charr Salvelinus alpinus (L.). Aquac Res 33, 543-546.

28. Skalli A, Castillo M, Andree KB, et al. (2013) The LPS derived from the cell walls of the gram-negative bacteria Pantoea agglomerans stimulates growth and immune status of rainbow trout (Oncorbynchus mykiss) juveniles. Aquaculture 416-417, 272-279.

29. Chakraborty SB, Horn P \& Hancz C (2013) Application of phytochemicals as growth-promoters and endocrine modulators in fish culture. Rev Aquacult 6, 1-19.

30. Lallès JP (2010) Intestinal alkaline phosphatase: multiple biological roles in maintenance of intestinal homeostasis and modulation by diet. Nutr Rev 68, 323-332.

31. Rønnestad I, Yúfera M, Ueberschär B, et al. (2013) Feeding behaviour and digestive physiology in larval fish: current knowledge, and gaps and bottlenecks in research. Rev Aquacult 5, S59-S98.

32. Calduch-Giner JA, Sitjà-Bobadilla A \& Pérez-Sánchez J (2016) Gene expression profiling reveals functional specialization along the intestinal tract of a carnivorous teleostean fish (Dicentrarchus labrax). Front Physiol 7, 359.

33. Katz JP, Perreault N, Goldstein BG, et al. (2002) The zinc-finger transcription factor Klf4 is required for terminal differentiation of goblet cells in the colon. Development 129, 2619-2628.

34. McGuckin MA, Lindén SK, Sutton P, et al. (2011) Mucin dynamics and enteric pathogens. Nat Rev Microbiol 9, $265-278$

35. Abreu MT, Fukata M \& Arditi M (2005) TLR signaling in the gut in health and disease. J Immunol 174, 4453-4460.

36. Smith P, MacDonald T \& Blumberg R (editors) (2012) Principles of Mucosal Immunology, Society for Mucosal Immunology]. New York: Garland Science. 
37. Kato M, Khan S, Gonzalez N, et al. (2003) Hodgkin's lymphoma cell lines express a fusion protein encoded by intergenically spliced mRNA for the multilectin receptor DEC-205 (CD205) and a novel C-type lectin receptor DCL-1. J Biol Chem 278, 34035-34041.

38. Watanabe Y, Naganuma T, Ogawwa T, et al. (2013) Lectins of marine origin and their clinical applications. In Lectins of Marine Origin and Their Antitumor Potential and Other Emerging Medicinal Properties of Natural Compounds, pp 33-54 [EF Fang and TB Ng, editors]. New York: Springer.

39. Schweickart VL, Epp A, Raport CJ, et al. (2000) CCR11 is a functional receptor for the monocyte chemoattractant protein family of chemokines. J Biol Chem 275, 9550-9556.

40. Li H, Limenitakis JP, Fuhrer T, et al. (2015) The outer mucus layer hosts a distinct intestinal microbial niche. Nat Commun 6, 8292 .

41. van Es JH, Haegebarth A, Kujala P, et al. (2012) A critical role for the Wnt effector Tcf4 in adult intestinal homeostatic selfrenewal. Mol Cell Biol 32, 1918-1927.

42. Schneeberger EE \& Lynch RD (2004) The tight junction: a multifunctional complex. Am I Physiol Cell Physiol 286, C1213-C1228.

43. Turner JR (2009) Intestinal mucosal barrier function in health and disease. Nat Rev Immunol 9, 799-809.

44. Saeki K, Suzuki H, Tsuneoka M, et al. (2000) Identification of mammalian TOM22 as a subunit of the preprotein translocase of the mitochondrial outer membrane. J Biol Chem 275 , 31996-32002

45. Wang Y, Katayama A, Terami T, et al. (2015) Translocase of inner mitochondrial membrane 44 alters the mitochondrial fusion and fission dynamics and protects from type 2 diabetes. Metabolism 64, 677-688.

46. Austin S \& St-Pierre J (2012) PGC1 $\alpha$ and mitochondrial metabolism - emerging concepts and relevance in ageing and neurodegenerative disorders. J Cell Sci 125, 4963-4973.

47. Arnould T, Michel S \& Renard P (2015) Mitochondria retrograde signaling and the $\mathrm{UPR}^{\mathrm{mt}}$ : where are we in mammals? Int J Mol Sci 16, 18224-18251.

48. Adhihetty PJ, Irrcher I, Joseph A-M, et al. (2003) Plasticity of skeletal muscle mitochondria in response to contractile activity. Exp Physiol 88, 99-107.
49. Zambonino-Infante JL \& Cahu CL (2007) Dietary modulation of some digestive enzymes and metabolic processes in developing marine fish: applications to diet formulation. Aquaculture 268, 98-105.

50. Gajda AM \& Storch J (2015) Enterocyte fatty acid binding proteins (FABPs): different functions of liver- and intestinalFABPs in the intestine. Prostaglandins Leukot Essent Fatty Acids 93, 9-16.

51. Gelebart P, Opas M \& Michalak M (2005) Calreticulin, a $\mathrm{Ca}^{2+}$-binding chaperone of the endoplasmic reticulum. Int J Biochem Cell Biol 37, 260-266.

52. Michalak M, Groenendyk J, Szabo E, et al. (2009) Calreticulin, a multiprocess calcium-buffering chaperone of the endoplasmic reticulum. Biochem J 417, 651-666.

53. Liu H, Peatman E, Wang W, et al. (2011) Molecular responses of calreticulin genes to iron overload and bacterial challenge in channel catfish (Ictalurus punctatus). Dev Comp Immunol 35, 267-272

54. Hou X, Xu S, Maitland-Toolan KA, et al. (2008) SIRT1 regulates hepatocyte lipid metabolism through activating AMP-activated protein kinase. J Biol Chem 283, 20015-20026.

55. Zang M, Maitland-Toolan KA, Zuccollo A, et al. (2006) Polyphenols stimulate AMP-activated protein kinase, lower lipids, and inhibit accelerated atherosclerosis in diabetic LDL receptor-deficient mice. Diabetes 55, 2180-2191.

56. Li S, Meng F, Liao X, et al. (2014) Therapeutic role of ursolic acid on ameliorating hepatic steatosis and improving metabolic disorders in high-fat diet-induced non-alcoholic fatty liver disease rats. PLOS ONE 9, e86724.

57. Rufino-Palomares EE, Reyes-Zurita FJ, García-Salguero L, et al. (2013) The role of maslinic acid in the pentose phosphate pathway during growth of gilthead sea bream (Sparus aurata). Aquac Nutr 19, 709-720.

58. Rufino-Palomares EE, Reyes-Zurita FJ, García-Salguero L, et al. (2016) NADPH production, a growth marker, is stimulated by maslinic acid in gilthead sea bream by increased NADP-IDH and ME expression. Comp Biochem Physiol C Toxicol Pharmacol 187C, 32-42.

59. Rufino-Palomares EE, Reyes-Zurita FJ, Fuentes-Almagro C, et al. (2011) Proteomics in the liver of gilthead sea bream (Sparus aurata) to elucidate the cellular response induced by the intake of maslinic acid. Proteomics 11, 3312-3325. 